\title{
PENGARUH PERBANDINGAN TEPUNG UBI JALAR UNGU DAN TEPUNG KEDELAI TERHADAP KARAKTERISTIK COOKIES
}

\author{
The Effect of Ratio Purple Sweet Potato Flour and Soybean Flour to The Characteristics of \\ Cookies
}

\author{
Putu Andi Sri Utami ${ }^{1}$, I Made Sugitha ${ }^{2}$, Ni Made Indri Hapsari Arihantana ${ }^{2}$ \\ ${ }^{1}$ Mahasiswa Jurusan Imu dan Teknologi Pangan, Fakultas Teknologi Pertanian, Unud \\ ${ }^{2}$ Dosen Jurusan Imu dan Teknologi Pangan, Fakultas Teknologi Pertanian, Unud \\ PS Ilmu dan Teknologi Pangan, Fakultas Teknologi Pertanian, Universitas Udayana, \\ Kampus Bukit Jimbaran, Badung-Bali
}

\begin{abstract}
This study aims to determine the effect of purple sweet potato flour and soybean flour to the characteristics of cookies produced and the ratio of purple sweet potato flour and soybean flour so that it can produce cookies with the best characteristics. The experimental design used was Completely Randomized Design with the ratio of purple sweet potato flour and soybean flour which consists of 6 levels: $100 \%: 0 \%$; $90 \%: 10 \% ; 80 \%: 20 \%$; 70\%:30\%; $60 \%: 40 \%$; and 50\%:50\%. The treatment was repeated 3 times to obtain 18 units of experiment. The data obtained were analyzed by variance and if the treatment had an effect on the observed variable then continued with The Duncan Multiple Range Test. The research showed that $70 \%$ of purple sweet potato flour with $30 \%$ of soybean flour produced the best cookies with characteristics of water content $3.37 \%$, ash content $1.43 \%$, protein content $12.73 \%$, lipid content $24.89 \%$, carbohydrate content $57.58 \%$, antioxidant activity $10.09 \%$, color rather liked, rather liked and very crispy texture, taste liked, aroma liked, and overall acceptance liked.
\end{abstract}

Keywords : wheat flour, cowpea, cowpea sprout flour, cookies

\section{PENDAHULUAN}

Cookies adalah salah satu jenis biskuit yang dibuat dari adonan lunak, berkadar lemak tinggi, relatif renyah bila dipatahkan dan penampang potongannya bertekstur kurang padat (Anon., 1992). Biasanya cookies dihidangkan pada hari raya besar, arisan, pada saat pertemuan keluarga ataupun sebagai cemilan. Di Indonesia, cookies merupakan salah satu jenis makanan yang banyak disukai oleh sebagian besar masyarakat, baik anakanak maupun orang dewasa. Sebagai makanan yang disukai masyarakat, diperlukan peningkatan nilai gizi cookies dan penganekaragaman produk cookies.
Bahan utama pembuatan cookies secara umum adalah terigu, sedangkan untuk bahan tambahannya adalah telur, gula halus, dan lemak. Kebutuhan terigu Indonesia tersebut terpenuhi dengan impor gandum karena Indonesia bukan negara penghasil gandum, hal ini berdampak pada meningkatnya impor terigu. Tahun 2015, impor terigu sudah mencapai 33.497 ton per tahun dan diperkirakan akan meningkat setiap tahunnya, sehingga perlu adanya upaya untuk mengurangi ketergantungan dalam impor terigu (Sarofa dkk., 2014). Namun, penggunaan terigu dalam pembuatan cookies dapat diganti menggunakan bahan lain seperti tepung ubi jalar ungu. Hal ini disebabkan

*Korespondensi Penulis:

Email: andiputu556@gmail.com ${ }^{1}$ 
karena produk cookies tidak memerlukan pengembangan yang tinggi. Susanti (2010) menyatakan bahwa penggunaan terigu dapat diganti $100 \%$ menggunakan tepung ubi jalar ungu pada pembuatan biskuit.

Ubi jalar ungu merupakan salah satu pangan lokal di Indonesia yang mengandung antosianin yang tinggi. Antosianin merupakan senyawa flavonoid pada ubi jalar ungu yang menyebabkan kulit dan daging umbi berwarna ungu. Antosianin berperan sebagai antioksidan yang dapat menangkal radikal bebas sehingga baik untuk menjaga kesehatan. Suprapta dkk. (2003), menyatakan bahwa ubi jalar ungu mengandung antosianin yang tinggi yaitu $110,51 \mathrm{mg} / 100 \mathrm{~g}$, pengolahan ubi jalar ungu menjadi tepung dapat memperpanjang umur simpannya serta dapat meningkatkan nilai ekonomisnya.

Tepung ubi jalar ungu memiliki kandungan karbohidrat yang tinggi sehingga baik digunakan untuk menghasilkan aneka produk pangan. Apabila dibandingkan dengan terigu yang mengandung protein sebanyak $9 \%$, tepung ubi jalar ungu hanya mengandung protein sebanyak 5,12\% per $100 \mathrm{~g}$ (Antarlina, 1998). Untuk melengkapi kandungan protein maka dapat ditambahkan dengan tepung kedelai. Kadar protein pada kedelai yaitu (35$38 \%$ ) lebih tinggi dibandingkan dengan jenis kacang-kacangan yang lain. Menurut Salim (2012), produk olahan kedelai merupakan sumber protein nabati yang banyak dikonsumsi oleh hampir seluruh lapisan masyarakat Indonesia, sehingga berperan dalam mendukung ketahanan pangan dan meningkatkan status gizi masyarakat.

Berdasarkan uraian diatas, maka penelitian ini dilakukan untuk mengetahui perbandingan tepung ubi jalar ungu dan tepung kedelai sehingga menghasilkan karakteristik cookies terbaik. Melalui penggunaan tepung ubi jalar ungu dan tepung kedelai dalam pembuatan cookies diharapkan dapat meningkatkan kandungan gizi cookies yang memanfaatkan pangan lokal, terutama terhadap kandungan protein dan antioksidan serta mengurangi ketergantungan pada pemakaian terigu.

\section{METODE PENELITIAN}

\section{Bahan dan alat}

Bahan-bahan yang digunakan dalam melaksanakan penelitian ini terdiri dari bahan baku, bahan tambahan, dan bahan kimia. Bahan baku terdiri dari ubi jalar ungu (varietas ayamurasaki) dan kacang kedelai (varietas anjasmoro) yang diperoleh dari pasar Badung. Bahan tambahan terdiri dari telur ayam negeri, margarin merk "Blueband", dan gula halus merk "Mawar" yang diperoleh dari UD. Menuh Gianyar. Bahan kimia yang digunakan dalam melakukan analisis meliputi $\mathrm{H}_{2} \mathrm{SO}_{4}$, $\mathrm{NaOH}, \mathrm{HCl}$, heksan, tablet Kjeldahl, asam borat, indikator PP, methanol dan diphenylpicrylhydrazyl (DPPH).

Alat-alat yang digunakan pada penelitian ini adalah baskom, gelas ukur, talenan, panci, mixer merk miyako, pisau, sendok, kompor merk rinnai, oven listrik merk cosmos, loyang, kuas, cetakan cookies, aluminium foil, dan parutan. Untuk analisis diperlukan alat-alat : timbangan analitik (Shimadzu), ayakan 60 mesh, tabung reaksi (Pyrex), gelas ukur (Pyrex), gelas beker (Pyrex), kertas saring, pipet tetes, corong, buret (Pyrex), desikator, vortex, cawan, labu Erlenmeyer(Pyrex), labu takar (Pyrex), labu Kjeldahl (Pyrex), muffle (Daihan), kertas saring, hot plate, pemanas listrik, dan corong kaca.

\section{Rancangan Penelitian}

Rancangan percobaan yang dipakai dalam penelitian ini adalah Rancangan Acak Lengkap dengan perlakuan perbandingan tepung ubi jalar ungu dan tepung kedelai, yaitu: $100 \%: 0 \%, 90 \%: 10 \%, 80 \%: 20 \%$, 70\% : 30\%, 60\% : 40\%, 50\% : 50\%. Masingmasing perlakuan diulang sebanyak 3 kali sehingga diperoleh 18 unit percobaan. Data yang diperoleh kemudian dianalisis dengan sidik ragam dan apabila terdapat pengaruh 
perlakuan terhadap variabel yang diamati, maka dilanjutkan dengan uji Duncan (Gomes dan Gomes, 1995).

\section{Pelaksanaan Penelitian}

Tahapan pertama yaitu pembuatan tepung ubi jalar ungu yaitu ubi jalar ungu dicuci dengan air hingga bersih kemudian dikupas kulitnya. Ubi jalar ungu kemudian diparut dan hasil parutan ditempatkan dalam loyang yang sudah dialasi aluminium foil dan diratakan. Loyang yang telah terisi dengan parutan ubi jalar ungu, dikeringkan di dalam oven pada suhu $60{ }^{\circ} \mathrm{C}$ selama 4 jam. Ubi jalar ungu yang sudah kering, kemudian dihaluskan dengan blender dan diayak dengan ayakan 60 mesh sehingga diperoleh tepung ubi jalar ungu (Ekawati dkk., 2013). (Ekawati dkk., 2013).

Tahapan kedua yaitu pembuatan tepung kedelai, dipilih kedelai yang mutunya baik yaitu tidak cacat dan tidak ada benda asing. Kedelai kemudian dicuci dengan air bersih yang mengalir, dengan pencucian ini kotorankotoran yang masih melekat maupun tercampur diantara kedelai dapat larut bersama air. Biji kedelai direndam selama 30 menit dalam air. Setelah itu ditiriskan dan dilanjutkan dengan perebusan kedelai selama 60 menit. Perebusan dilakukan untuk mengurangi aroma langu pada kedelai dan dibuang kulit arinya. Kulit ari tidak digunakan untuk mengurangi kandungan lemaknya dan mengurangi aroma langu yang terdapat pada kedelai. Selanjutnya kedelai ditiriskan dan didinginkan, kemudian dikeringkan selama 20 jam dengan suhu $60^{\circ} \mathrm{C}$, pengeringan dilakukan di dalam oven. Setelah kedelai kering kemudian kedelai dihaluskan dengan blender, kemudian diayak dengan ayakan 60 mesh sehingga diperoleh tepung kedelai (Kariadi, 1993, yang dimodifikasi).

Tahapan ketiga yaitu pembuatan cookies tepung ubi jalar ungu dan tepung kedelai, proses pembuatan cookies dimulai dengan menimbang tepung ubi jalar ungu dan tepung kedelai sesuai perlakuan. Proses selanjutnya adalah menimbang margarin, gula halus, dan telur untuk masing-masing adonan. Selanjutnya margarin dan gula halus dicampur menggunakan mixer selama 1 menit. Selanjutnya ditambahkan telur pada adonan mixer selama 1 menit. Selanjutnya ditambahkan tepung ubi jalar ungu dan tepung kedelai sesuai perlakuan, diaduk menggunakan sendok kayu hingga adonan menjadi kalis selama 1 menit. Adonan yang sudah kalis kemudian dicetak dengan cetakan cookies. Selanjutnya dipanggang dalam oven selama 25 menit pada suhu $160^{\circ} \mathrm{C}$. Setelah adonan matang dilakukan tempering atau pendinginan cookies selama 15 menit sampai suhu $27^{\circ} \mathrm{C}$. Cookies tepung ubi jalar ungu dan tepung kedelai siap dianalaisis (Marina, 2012, yang dimodifikasi).

\section{Variabel Yang Diamati}

Variabel yang diamati dalam penelitian ini adalah kadar air dilakukan dengan metode pengeringan (Sudarmadji dkk., 1997), kadar abu dilakukan dengan metode pengabuan (Sudarmadji dkk., 1997), kadar protein dengan metode Mikro-Kjeldahl (Sudarmadji dkk., 1997), kadar lemak dilakukan dengan metode soxhlet (Sudarmadji dkk., 1997), kadar karbohidrat dilakukan dengan metode Carbohydrate by different (Sudarmadji dkk., 1997), aktivitas antioksidan dengan metode DPPH (Khan dkk., 2012), sifat sensoris terhadap warna, tekstur, rasa, aroma, dan penerimaan keseluruhan (Soekarto, 1985).

\section{HASIL DAN PEMBAHASAN}

Hasil analisis kadar air, kadar abu, kadar protein, kadar lemak, kadar karbohidrat, dan aktivitas antioksidan dari tepung ubi jalar ungu dan tepung kedelai dapat dilihat pada Tabel 1 .

Tepung ubi jalar ungu memiliki kadar air yaitu $7,03 \%$, kadar abu yaitu $1,10 \%$, kadar protein yaitu 5,44\%, kadar lemak yaitu $0,89 \%$, kadar karbohidrat yaitu $85,54 \%$, dan aktivitas antioksidan yaitu $15,03 \%$. Tepung kedelai 
kadar air yaitu 6,08\%, kadar abu yaitu 2,60\%, kadar protein yaitu 30,03\%, kadar lemak yaitu $17,36 \%$, kadar karbohidrat yaitu 43,93\%, dan aktivitas antioksidan yaitu $3,65 \%$.
Hasil analisis kadar air, kadar abu, kadar protein, kadar lemak, kadar karbohidrat, dan aktivitas antioksidan pada cookies dapat dilihat pada Tabel 2.

Tabel 1. Nilai rata-rata hasil analisis kadar air, kadar abu, kadar prorein, kadar lemak, kadar karbohidrat dan aktivitas antioksidan tepung ubi jalar ungu dan tepung kedelai

\begin{tabular}{lcccccc}
\hline \multicolumn{1}{c}{ Perlakuan } & $\begin{array}{c}\text { Kadar } \\
\text { Air (\%) }\end{array}$ & $\begin{array}{c}\text { Kadar } \\
\text { Abu (\%) }\end{array}$ & $\begin{array}{c}\text { Kadar } \\
\text { Protein (\%) }\end{array}$ & $\begin{array}{c}\text { Kadar } \\
\text { Lemak (\%) }\end{array}$ & $\begin{array}{c}\text { Kadar } \\
\text { Karbohidrat (\%) }\end{array}$ & $\begin{array}{c}\text { Aktivitas } \\
\text { Antioksidan (\%) }\end{array}$ \\
\hline $\begin{array}{l}\text { Tepung Ubi Jalar } \\
\text { Ungu }\end{array}$ & 7,03 & 1,10 & 5,44 & 0,89 & 85,54 & 15,03 \\
Tepung Kedelai & 6,08 & 2,60 & 30,03 & 17,36 & 43,93 & 3,65 \\
\hline
\end{tabular}

Tabel 2. Nilai rata-rata kadar air, kadar abu, kadar protein, kadar lemak, kadar karbohidrat, dan aktivitas antioksidan cookies

\begin{tabular}{|c|c|c|c|c|c|c|}
\hline Perlakuan & $\begin{array}{r}\text { Kadar } \\
\text { Air }(\%)\end{array}$ & $\begin{array}{c}\text { Kadar } \\
\text { Abu (\%) }\end{array}$ & $\begin{array}{c}\text { Kadar } \\
\text { Protein }(\%)\end{array}$ & $\begin{array}{c}\text { Kadar } \\
\text { Lemak }(\%)\end{array}$ & $\begin{array}{c}\text { Kadar } \\
\text { Karbohidrat (\%) }\end{array}$ & $\begin{array}{c}\text { Aktivitas } \\
\text { Antioksidan (\%) }\end{array}$ \\
\hline \multirow[t]{2}{*}{ P0 } & 3,81 & 1,21 & 6,84 & 21,49 & 66,65 & 12,23 \\
\hline & $\pm 0,07 \mathrm{a}$ & $\pm 0,05 \mathrm{e}$ & $\pm 0,07 \mathrm{f}$ & $\pm 0,08 \mathrm{~d}$ & $\pm 0,11 \mathrm{a}$ & $\pm 0,23 \mathrm{a}$ \\
\hline \multirow[t]{2}{*}{ P1 } & 3,68 & 1,32 & 9,66 & 22,64 & 62,70 & 11,53 \\
\hline & $\pm 0,09 \mathrm{~b}$ & $\pm 0,03 \mathrm{~d}$ & $\pm 0,35 \mathrm{e}$ & $\pm 0,35 \mathrm{c}$ & $\pm 0,78 \mathrm{~b}$ & $\pm 0,17 \mathrm{a}$ \\
\hline \multirow[t]{2}{*}{$\mathrm{P} 2$} & 3,57 & 1,38 & 11,25 & 23,29 & 60,50 & 10,61 \\
\hline & $\pm 0,02 \mathrm{c}$ & $\pm 0,01 \mathrm{c}$ & $\pm 0,24 \mathrm{~d}$ & $\pm 0,72 \mathrm{c}$ & $\pm 0,96 \mathrm{c}$ & $\pm 0,48 \mathrm{~b}$ \\
\hline \multirow[t]{2}{*}{ P3 } & 3,37 & 1,43 & 12,73 & 24,89 & 57,58 & 10,09 \\
\hline & $\pm 0,09 \mathrm{~d}$ & $\pm 0,03 \mathrm{~b}$ & $\pm 0,13 \mathrm{c}$ & $\pm 0,48 \mathrm{~b}$ & $\pm 0,65 \mathrm{~d}$ & $\pm 0,13 \mathrm{bc}$ \\
\hline \multirow[t]{2}{*}{ P4 } & 3,21 & 1,46 & 13,83 & 25,78 & 55,72 & 9,39 \\
\hline & $\pm 0,02 \mathrm{e}$ & $\pm 0,01 \mathrm{ab}$ & $\pm 0,12 \mathrm{~b}$ & $\pm 0,71 \mathrm{~b}$ & $\pm 0,82 \mathrm{e}$ & $\pm 0,51 \mathrm{c}$ \\
\hline \multirow[t]{2}{*}{ P5 } & 2,92 & 1,48 & 15,25 & 26,74 & 53,61 & 8,40 \\
\hline & $\pm 0,01 \mathrm{f}$ & $\pm 0,01 \mathrm{a}$ & $\pm 0,40 \mathrm{a}$ & $\pm 0,46 \mathrm{a}$ & $\pm 0,86 \mathrm{f}$ & $\pm 0,67 \mathrm{~d}$ \\
\hline
\end{tabular}

Keterangan : Nilai rata - rata yang diikuti oleh huruf yang berbeda pada kolom yang sama menunjukkan berbeda nyata pada Uji Duncan 0,05.

\section{Kadar Air}

Hasil sidik ragam menunjukkan bahwa perbandingan tepung ubi jalar ungu dengan tepung kedelai berpengaruh sangat nyata $(\mathrm{P}<0,01)$ terhadap kadar air cookies. Tabel 2 menunjukkan kadar air cookies tertinggi diperoleh dari perlakuan P0 yaitu 3,81\%, sedangkan kadar air cookies terendah diperoleh dari perlakuan P5 yaitu 2,92\%.

Penurunan kadar air terjadi seiring meningkatnya panambahan tepung kedelai, hal ini disebabkan karena kadar air tepung kedelai lebih rendah dibandingkan tepung ubi jalar ungu. Kadar air tepung ubi jalar ungu adalah 7,03\% sedangkan kadar air kedelai adalah 6,08\%. Nilai kadar air menurut SNI cookies maksimal 5\% (Anon., 1992), jadi kadar air cookies yang dihasilkan telah memenuhi SNI cookies.

\section{Kadar Abu}

Hasil sidik ragam menunjukkan bahwa perbandingan tepung ubi jalar ungu dengan tepung kedelai berpengaruh sangat nyata $(\mathrm{P}<0,01)$ terhadap kadar abu cookies. Tabel 2 menunjukkan kadar abu cookies tertinggi diperoleh dari perlakuan P5 yaitu 1,48\% serta tidak berbeda dengan perlakuan $\mathrm{P} 4$, sedangkan kadar air cookies terendah diperoleh dari perlakuan P0 yaitu 1,21\%.

Semakin meningkat penggunaan tepung kedelai menyebabkan kadar abu cookies semakin meningkat. Hal ini disebabkan karena kadar abu tepung kedelai lebih tinggi dibandingkan tepung ubi jalar ungu. Kadar abu 
tepung kedelai adalah 2,60\% sedangkan kadar abu tepung ubi jalar ungu adalah $1,10 \%$. Kadar abu dari suatu bahan menunjukkan total mineral yang terkandung dalam bahan tersebut. Beberapa fungsi mineral dalam tubuh diantaranya kalsium berperan dalam membentuk tulang dan gigi serta mengatur proses biologis, fosfor berperan dalam penyimpanan dan pengeluaran energi (Winarno, 2002). Nilai kadar abu menurut SNI cookies maksimal 1,5\% (Anon., 1992), jadi kadar abu cookies yang dihasilkan telah memenuhi SNI cookies.

\section{Kadar protein}

Hasil sidik ragam menunjukkan bahwa perbandingan tepung ubi jalar ungu dengan tepung kedelai berpengaruh sangat nyata $(\mathrm{P}<0,01)$ terhadap kadar protein cookies. Tabel 2 menunjukkan kadar protein cookies tertinggi diperoleh dari perlakuan P5 yaitu 15,25\% sedangkan kadar protein terendah diperoleh dari perlakuan P0 yaitu 6,84\%.

Semakin meningkat penggunaan tepung kedelai menyebabkan kadar protein cookies semakin meningkat. Hal ini disebabkan karena kadar protein tepung kedelai lebih tinggi dibandingkan dengan tepung ubi jalar ungu. Kadar protein tepung kedelai adalah 30,03\% sedangkan kadar protein tepung ubi ungu adalah 5,44\%. Protein merupakan suatu zat makanan yang amat penting bagi tubuh, karena berfungsi sebagai bahan pembentuk jaringan-jaringan baru yang selalu terjadi dalam tubuh, mengganti jaringan tubuh yang rusak serta mempertahankan jaringan yang sudah ada (Winarno, 2002). Nilai kadar protein menurut SNI cookies minimum 9\% (Anon., 1992), perlakuan yang sudah memenuhi SNI adalah P1, P2, P3, P4, dan P5 sedangkan perlakuan yang tidak memenuhi SNI adalah P0.

\section{Kadar Lemak}

Hasil sidik ragam menunjukkan bahwa perbandingan tepung ubi jalar ungu dengan tepung kedelai berpengaruh sangat nyata $(\mathrm{P}<0,01)$ terhadap kadar lemak cookies. Tabel 2 menunjukkan kadar lemak cookies tertinggi diperoleh dari perlakuan P5 yaitu 26,74\% sedangkan kadar lemak terendah diperoleh dari perlakuan P0 yaitu 21,49\%.

Semakin meningkat penggunaan tepung kedelai menyebabkan kadar lemak cookies semakin meningkat. Hal ini disebabkan karena kadar lemak tepung kedelai lebih tinggi dibandingkan dengan tepung ubi jalar ungu. Kadar lemak tepung kedelai adalah 17,36\% sedangkan kadar lemak tepung ubi jalar ungu adalah $0,89 \%$. Lemak adalah komponen bahan pangan yang menyediakan energi paling tinggi. Selain berfungsi dari segi gizi, lemak juga berperan dalam pembentukan tekstur dan citra rasa produk (Winarno, 2004). Nilai kadar lemak menurut SNI cookies minimum 9,5\% (Anon., 1992), jadi kadar lemak cookies yang dihasilkan telah memenuhi SNI cookies.

\section{Kadar Karbohidrat}

Hasil sidik ragam menunjukkan bahwa perbandingan tepung ubi jalar ungu dengan tepung kedelai berpengaruh sangat nyata $(\mathrm{P}<0,01)$ terhadap kadar karbohidrat cookies. Tabel 2 menunjukkan kadar karbohidrat cookies tertinggi diperoleh dari perlakuan P0 yaitu $66,65 \%$, sedangkan kadar karbohidrat terendah diperoleh dari perlakuan P5 yaitu $53,61 \%$.

Semakin meningkat penggunaan tepung kedelai menyebabkan kadar karbohidrat cookies semakin rendah. Hal ini disebabkan karena kadar karbohidrat tepung kedelai lebih rendah dibandingkan dengan tepung ubi jalar ungu. Kadar karbohidrat tepung ubi ungu adalah $85,54 \%$ sedangkan kadar karbohidrat tepung kedelai adalah $43,93 \%$. Menurut Sugito dan Hayati (2006), kadar karbohidrat yang dihitung secara By difference dipengaruhi oleh komponen nutrisi lain, semakin rendah komponen nutrisi lain maka kadar karbohidrat akan semakin tinggi. Begitu juga sebaliknya semakin tinggi komponen nutrisi lain maka 
kadar karbohidrat akan semakin rendah. Komponen nutrisi yang mempengaruhi besarnya kandungan karbohidrat diantaranya adalah kandungan protein, lemak, air dan abu.

\section{Aktivitas Antioksidan}

Hasil sidik ragam menunjukkan bahwa perbandingan tepung ubi jalar ungu dengan tepung kedelai berpengaruh sangat nyata $(\mathrm{P}<0,01)$ terhadap aktivitas antioksidan cookies. Tabel 2 menunjukkan aktivitas antioksidan tertinggi diperoleh dari perlakuan P0 yaitu $12,23 \%$ serta tidak berbeda dengan P1 sedangkan aktivitas antioksidan terendah diperoleh dari perlakuan P5 yaitu 8,40\%.

Semakin meningkat penggunaan tepung kedelai menyebabkan aktivitas antioksidan cookies semakin rendah. Hal ini disebabkan karena aktivitas antioksidan tepung kedelai lebih rendah dibandingkan dengan aktivitas antioksidan tepung ubi ungu. Aktivitas antioksidan tepung ubi ungu adalah 15, 03\% sedangkan aktivitas antioksidan tepung kedelai adalah 3,65\%. Tepung ubi jalar ungu mengandung antosianin yang termasuk golongan senyawa flavonoid. Kelompok senyawa flavonoid seperti antosianin merupakan salah satu kelompok bahan alami pada tumbuhan yang berperan sebagai antioksidan (Pieta, 2000).

\section{Evaluasi Sensoris}

Evaluasi sensori cookies dilakukan dengan uji hedonik terhadap warna, tekstur, rasa, aroma, dan penerimaan keseluruhan. Uji skoring dilakukan terhadap warna dan tekstur cookies. Nilai rata-rata uji hedonik terhadap warna, tekstur, rasa, aroma dan penerimaan keseluruhan cookies dapat dilihat pada Tabel 3. Nilai rata-rata uji skoring terhadap warna dan tekstur dapat dilihat pada pada Tabel 4 .

Tabel 3. Nilai rata-rata uji hedonik warna, tekstur, rasa, aroma dan penerimaan keseluruhan

\begin{tabular}{|c|c|c|c|c|c|}
\hline \multirow[t]{2}{*}{ Perlakuan } & \multicolumn{5}{|c|}{ Nilai rata-rata uji hedonik } \\
\hline & Warna & Tekstur & Rasa & Aroma & Penerimaan keseluruhan \\
\hline \multirow[t]{2}{*}{ P0 } & 5,93 & 5,80 & 4,80 & 4,60 & 5,07 \\
\hline & $\pm 1,16 \mathrm{a}$ & $\pm 0,86 \mathrm{ab}$ & $\pm 1,01 \mathrm{~b}$ & $\pm 1,18 \mathrm{c}$ & $\pm 0,96 \mathrm{bc}$ \\
\hline \multirow[t]{2}{*}{ P1 } & 5,47 & 5,73 & 5,67 & 4,93 & 4,73 \\
\hline & $\pm 1,13 \mathrm{ab}$ & $\pm 0,70 \mathrm{abc}$ & $\pm 0,72 \mathrm{a}$ & $\pm 0,88 \mathrm{bc}$ & $\pm 1,10 \mathrm{c}$ \\
\hline \multirow[t]{2}{*}{$\mathrm{P} 2$} & 5,27 & 5,20 & 5,47 & 5,27 & 5,60 \\
\hline & $\pm 1,03 \mathrm{ab}$ & $\pm 0,86 \mathrm{bcd}$ & $\pm 0,74 \mathrm{ab}$ & $\pm 0,88 \mathrm{abc}$ & $\pm 0,83 \mathrm{ab}$ \\
\hline \multirow[t]{2}{*}{ P3 } & 5,13 & 6,07 & 5,80 & 5,73 & 6,07 \\
\hline & $\pm 1,30 \mathrm{ab}$ & $\pm 0,80 \mathrm{a}$ & $\pm 0,78 \mathrm{a}$ & $\pm 0,59 \mathrm{a}$ & $\pm 0,88 \mathrm{a}$ \\
\hline \multirow[t]{2}{*}{ P4 } & 4,93 & 5,07 & 5,33 & 5,07 & 5,27 \\
\hline & $\pm 0,88 \mathrm{bc}$ & $\pm 1,03 \mathrm{~cd}$ & $\pm 1,11 \mathrm{ab}$ & $\pm 1,03 \mathrm{abc}$ & $\pm 0,80 \mathrm{bc}$ \\
\hline \multirow[t]{2}{*}{ P5 } & 4,13 & 4,73 & 5,40 & 5,40 & 5,53 \\
\hline & $\pm 1,30 \mathrm{c}$ & $\pm 0,96 \mathrm{~d}$ & $\pm 0,73 \mathrm{ab}$ & $\pm 1,06 \mathrm{ab}$ & $\pm 0,52 \mathrm{ab}$ \\
\hline
\end{tabular}

Keterangan : Nilai rata - rata yang diikuti oleh huruf yang berbeda pada kolom yang sama menunjukkan berbeda nyata pada Uji Duncan $(\mathrm{P}<0,05)$.

Kriteria hedonik : 1 (sangat tidak suka), 2 (tidak suka), 3 (agak tidak suka), 4 (biasa), 5 (agak suka), 6 (suka), 7 (sangat suka).

\section{Warna}

Hasil sidik ragam menunjukkan bahwa perbandingan tepung ubi jalar ungu dengan tepung kedelai berpengaruh sangat nyata $(\mathrm{P}<0,01)$ terhadap warna (uji hedonik) cookies. Tabel 3 menunjukkan bahwa nilai rata-rata tertinggi diperoleh dari cookies dari perlakuan P0 yaitu 5,93 (suka) dan tidak berbeda dengan $\mathrm{P} 1$, P2, dan P3, sedangkan nilai terendah diperoleh dari cookies pada perlakuan P5 yaitu 4,13 (biasa) dan tidak berbeda dengan P4.

Menurut Winarno (2004) warna merupakan komponen yang sangat penting untuk 
Tabel 4. Nilai rata-rata uji skoring warna dan tekstur cookies

\begin{tabular}{cc}
\hline Perlakuan & Nilai rata-rata uji skoring tekstur \\
\hline P0 & $3,07 \pm 0,88 \mathrm{~b}$ \\
P1 & $3,20 \pm 0,68 \mathrm{~b}$ \\
P2 & $3,47 \pm 0,52 \mathrm{ab}$ \\
P3 & $3,93 \pm 0,80 \mathrm{a}$ \\
P4 & $3,60 \pm 0,83 \mathrm{ab}$ \\
P5 & $3,53 \pm 0,64 \mathrm{ab}$ \\
\hline
\end{tabular}

Keterangan : Nilai rata - rata yang diikuti oleh huruf yang berbeda pada kolom yang sama menunjukkan berbeda nyata pada Uji Duncan $(\mathrm{P}<0,05)$.

Kriteria tekstur : 1 (tidak renyah), 2 (agak renyah), 3 (renyah), 4 (sangat renyah), 5 (amat sangat renyah).

menentukan kualitas atau derajat penerimaan suatu bahan pangan. Suatu bahan pangan meskipun dinilai enak dan teksturnya sangat baik, tetapi memiliki warna yang tidak menarik atau memberi kesan telah menyimpang dari warna yang seharusnya maka bahan tersebut tidak akan dikonsumsi. Penentuan mutu suatu bahan pangan pada umumnya tergantung pada warna karena warna tampil terlebih dahulu.

\section{Tekstur}

Hasil sidik ragam menunjukkan bahwa perbandingan tepung ubi jalar ungu dengan tepung kedelai berpengaruh sangat nyata $(\mathrm{P}<0,01)$ terhadap tekstur (uji hedonik) cookies. Tabel 3 menunjukkan bahwa nilai rata-rata tertinggi diperoleh dari cookies dari perlakuan P3 yaitu 6,07 (suka) dan tidak berbeda dengan P0 dan P1, sedangkan nilai terendah diperoleh dari cookies pada perlakuan P5 yaitu 4,73 (agak suka) dan tidak berbeda dengan P2 dan P4.

Hasil sidik ragam menunjukkan bahwa perbandingan tepung ubi jalar ungu dan tepung kedelai berpengaruh nyata $(\mathrm{P}<0,05)$ terhadap tekstur (uji skoring) cookies. Tabel 4 menunjukkan bahwa nilai terhadap tekstur (uji skoring) tertinggi cookies diperoleh pada perlakuan P3 yaitu 3,93 (sangat renyah) dan tidak berbeda dengan P2, P4, dan P5, sedangkan nilai terendah cookies diperoleh pada perlakuan P0 yaitu 3,07 (renyah) dan tidak berbeda dengan P1.

\section{Rasa}

Hasil sidik ragam menunjukkan bahwa perbandingan tepung ubi jalar ungu dengan tepung kedelai berpengaruh nyata $(\mathrm{P}<0,05)$ terhadap rasa. Tabel 3 menunjukkan bahwa tertinggi diperoleh dari cookies dari perlakuan P3 yaitu 5,80 (suka) dan tidak berbeda dengan P1, P2, P4, dan P5 sedangkan nilai terendah diperoleh dari cookies pada perlakuan P0 yaitu 4,80 (agak suka).

Menurut Khasanah (2003) menyatakan bahwa rasa adalah faktor yang dinilai panelis setelah warna, aroma dan tekstur yang dapat yang mempengaruhi penerimaan produk pangan. Rasa timbul akibat adanya rangsangan kimiawi yang dapat diterima oleh indera pencicip atau lidah. Rasa yang enak dapat menarik perhatian sehingga konsumen lebih cenderung menyukai makanan dari rasanya. Jika komponen aroma, warna dan tekstur baik tetapi konsumen tidak menyukai rasanya maka konsumen tidak akan menerima produk pangan tersebut.
Aroma
Hasil sidik ragam menunjukkan bahwa perbandingan tepung ubi jalar ungu dengan tepung kedelai berpengaruh nyata $(\mathrm{P}<0,05)$ terhadap aroma. Tabel 3 menunjukkan bahwa tertinggi diperoleh dari cookies dari perlakuan P3 yaitu 5,73 (suka) dan tidak berbeda dengan P2, P4, dan P5, sedangkan nilai terendah diperoleh dari cookies pada perlakuan P0 yaitu 4,60 (agak suka) dan tidak berbeda dengan P1. 


\section{Penerimaan Keseluruhan}

Hasil sidik ragam menunjukkan bahwa perbandingan tepung ubi jalar ungu dengan tepung kedelai berpengaruh sangat nyata $(\mathrm{P}<0,01)$ terhadap penerimaan keseluruhan. Tabel 3 menunjukkan bahwa tertinggi diperoleh dari cookies dari perlakuan $\mathrm{P} 3$ yaitu 6,07 (suka) dan tidak berbeda dengan P2 dan $\mathrm{P} 5$, sedangkan nilai terendah diperoleh dari cookies pada perlakuan P1 yaitu 4,73 (agak suka) dan tidak berbeda dengan P0, P4. Penerimaan keseluruhan cookies dipengaruhi oleh beberapa faktor seperti warna, aroma, tekstur, dan rasa.

\section{SIMPULAN DAN SARAN}

\section{Simpulan}

Berdasarkan hasil penelitian ini dapat disimpulkan sebagai berikut :

1. Perbandingan tepung ubi jalar ungu dengan tepung kedelai berpengaruh terhadap kadar air, kadar abu, kadar lemak, kadar protein, kadar karbohidrat, aktivitas antioksidan, warna (uji hedonik), tekstur (uji hedonik dan skoring), aroma (uji hedonik), rasa (uji hedonik) serta penerimaan keseluruhan (uji hedonik) cookies.

2. Perlakuan perbandingan $70 \%$ tepung ubi jalar ungu dengan 30\% tepung kedelai menghasilkan cookies dengan karakteristik terbaik yaitu: kadar air $3,37 \%$, kadar abu 1,43\%, kadar protein $12,73 \%$, kadar lemak 24,89\%, kadar karbohidrat $57,58 \%$, aktivitas antioksidan $10,09 \%$, warna agak suka, tekstur suka dan sangat renyah, rasa suka, aroma suka, serta penerimaan keseluruhan suka.

\section{Saran}

Berdasarkan hasil penelitian ini disarankan untuk :

Menggunakan perbandingan $70 \%$ tepung ubi jalar ungu dengan 30\% tepung kedelai dalam proses pembuatan cookies.

\section{DAFTAR PUSTAKA}

Anonimus. 1992. Syarat Mutu Cookies. SNI 01-2973-1992. Badan Stadarisasi Nasional. Departemen Perindustrian. Jakarta.

Antarlina, S.S. 1998. Proses Pembuatan dan Penggunaan Tepung Ubi Jalar Ungu Untuk Produk Pangan. Balai Penelitian Tanaman Kacang-kacangan dan Umbi-umbian. Malang.

Ekawati, I. G. A., N. M. I. H. Arihantana dan P. A. S Wipradnyadewi. 2013. Pemanfaatan Tepung Ubi Ungu Termodifikasi Sebagai Pangan Sehat. Laporan Penelitian Hibah Bersaing. Universitas Udayana.

Gomes, K. A. dan A. A. Gomes. 1995. Prosedur Statistik Untuk Penelitian Pertanian. UI Press, Jakarta.

Kariadi, O.K. 1993. Pengaruh Lama Perebusan Kedelai Terhadap Karakteristik Tepung Kedelai. Program Studi Teknologi Pertanian. Fakultas Pertanian. Universitas Udayana. Denpasar.

Khan, R.A., M.R. Khan., S. Sahreen., dan M. Ahme. 2012. Evaluation of phenolic contents and antioxidant activity of various solvent extracts of Sonchus asper (L.) Hill. Chemistry Central Journal. 6(1):1-6.

Khasanah, U. 2003. Formulasi Karakterisasi Fisiko-Kimia dan Organoleptik Produk Makanan Sarapan Ubi Jalar. Skripsi. Fakultas Teknologi Pertanian. Institut Pertanian Bogor, Bogor.

Marina, A. 2012. Pemanfaatan Ekstraksi Kulit Ari Biji Kakao (Theobroma cacao L) Pada Produk Cookies Coklat. Universitas Hassanudin. Makasar.

Pieta. P G. 2000. Flavonoid as Antioxidant. J. matt prod $63: 1035$ - 1043.

Salim, E. 2012. Kiat Cerdas Wirausaha Aneka Olahan Kedelai. Yogyakarta: Lyli Publisher. 
Sarofa, U., S. Djajati, dan S.N. Cholifah. 2014. Pembuatan Roti Manis (Kajian Substitusi Tepung Terigu Dan Kulit Manggis Dengan Penambahan Gluten). Jurnal Rekapangan Vol. 8 No.2. Hal. 171-178.

Soekarto, S.T. 1985. Penilaian Organoleptik Untuk Industri Pangan dan Hasil Pertanian, Bhratara Aksara, Jakarta.

Sudarmaji, S., B. Haryono dan Suhardi. 1997. Prosedur Analisa Bahan Makanan dan Pertanian. Liberty. Yogyakarta.

Sugito dan A. Hayati. 2006. Penambahan Daging Ikan Gabus (Ophicepallus strianus) dan Aplikasi Pembekuan pada Pembuatan Pempek Gluten. Jurnal Ilmu-Ilmu Pertanian Indonesia Vol. 14 No. 1 : 9-20.

Suprapta, D. N., M. Antara, N. Arya, M. Sudana, A. S. Duniaji, dan M. Sudarma. 2003. Penelitian Peningkatan Kualitas dan Diversifikasi Penggunaan Umbi-umbian sebagai Sumber Pangan Alternatif di Bali.

Laporan hasil Penelitian Kerjasama BAPPEDA Provinsi Bali dan Fakultas Pertanian UNUD, Denpasar.

Susanti, D. 2010. Pengaruh Perbandingan Terigu dan Tepung Ubi jalar ungu (Ipomoea batatas var Ayamurasaki) terhadap Karakteristik Biskuit. Skripsi. Fakultas Teknologi Pertanian, Universitas Udayana, Bukit Jimbaran.

Winarno, F. G. 2002. Kimia Pangan dan Gizi. Gramedia Pustaka Utama, Jakarta.

Winarno, F. G. 2004. Hasil-hasil Simposium Penganekaragaman Pangan. Prakarsa Swasta dan Pemda, Jakarta. 